\title{
Cancer in Cumbria and in the vicinity of the Sellafield nuclear installation, 1963-90
}

\author{
G J Draper, C A Stiller, R A Cartwright, A W Craft, T J Vincent
}

\begin{abstract}
Objective-To reappraise the epidemiological findings reported by the Black Advisory Group concerning a possible excess of malignant disease, particularly of childhood acute lymphoid leukaemia and non-Hodgkin lymphomas, in the vicinity of the Sellafield nuclear installation, and to determine whether any excess of malignant disease had occurred among people aged 0-24 years in the area in the years after the Black report-that is, from 1984 to 1990.
\end{abstract}

Design-Calculation of incidence of cancer using data from population based cancer registries and special surveys.

Setting-England and Wales; county of Cumbria; county districts Allerdale and Copeland within Cumbria; Seascale ward within Copeland.

Subjects-All residents under the age of 75 years in the above areas, but with particular reference to those aged 0-24 years.

Main outcome measures-Numbers of cases and incidence particularly of lymphoid leukaemia and non-Hodgkin lymphomas in those aged $0-24$ years, but including other cancers and age groups.

Results-Previous reports of an increased incidence of cancer, especially of leukaemia, among those aged 0-24 years in Seascale during the period up to and including 1983 are confirmed. During 1984-90 there was an excess of total cancer among those aged 0-24 years. This was based on four cases including two cases of non-Hodgkin lymphoma but none of leukaemia. There was an increased, but nonsignificant, incidence of other cancers, based on two cases (one pinealoma and one Hodgkin's disease) occurring among those aged 15-24 years during 1984-90. This was not observed in the younger age group or in previous years. For the immediately surrounding area-that is, the county districts of Allerdale and Copeland excluding Seascale and in the remainder of Cumbria-there was no evidence of an increased incidence of cancer among those aged 0-24 years in either period.

Conclusions-During 1963-83 and 1984-90 the incidence of malignant disease, particularly lymphoid leukaemia and non-Hodgkin lymphomas, in young people aged 0-24 in Seascale was higher than would be expected on the basis of either national rates or those for the surrounding areas. Although this increased risk is unlikely to be due to chance, the reasons for it are still unknown.

Children's Department, Royal Victoria Infirmary, Newcastle upon Tyne NE1 4LP

A W Craft, professor

Correspondence to: Dr Draper.

BMF 1993;306:89-94 of an increased incidence of cancer, or of clusters of cases, in the vicinity of nuclear installations. The most detailed investigations have concerned the Sellafield nuclear reprocessing plant in West Cumbria. An advisory group chaired by Sir Douglas Black investigated the suggestion that there was an increased incidence of cancer in the vicinity of this installation. This group produced a report discussing the discharges around the site and the extent of radiation exposures and giving estimates of the likely risks.' The report included a series of epidemiological analyses and also contained lists of patients resident in Seascale and the surrounding area. The analyses covered a variety of diagnostic groups, age groups, and periods.

Few other areas have been the subject of systematic epidemiological studies: in the United Kingdom such studies include those of Dounreay, ${ }^{2}$ of Aldermaston and Burghfield, ${ }^{3}$ and of nuclear installations generally. ${ }^{4}$

Since the Black report further cohort and casecontrol studies of the area around Sellafield have been carried out, ${ }^{5-7}$ but there has been no comprehensive analysis of cancer incidence.

This report includes analyses of the incidence of cancer among people aged 0-24 years during the period up to 1983. These analyses are based on more complete data than were available to the authors of the Black report. Although the data are not directly comparable with those in previously published analyses, they are nevertheless subject to the major criticism of the studies discussed in the Black report-namely, that the results were vitiated by biased selection of diagnostic groups, age groups, calendar periods, and areas. Although the Black report does not contain any explicit statement about the period that it covers, none of the analyses on which it is based go beyond 1983. Our report is mainly concerned with 1984 onwards. In planning our analyses we were concerned to avoid the biases that affected the analyses of the period up to and including 1983; it was agreed in advance, at a meeting of a working group of the Committee on Medical Aspects of Radiation in the Environment, that the principal hypothesis to be tested should be that "no excess of leukaemia or other cancer in 0-24 year olds has occurred in the area of the Sellafield plant from 1984 to the present," and that the diagnostic groups, areas, and calendar periods to be analysed should be those set out below.

\section{Methods}

DIAGNOSTIC GROUPS

In planning this report it was agreed that the analyses would cover both total malignant disease around Sellafield and also several individual diagnostic groups. The diagnostic groups were defined as follows, the disease categories in brackets referring to the standard classification for childhood cancer: (a) lymphoid leukaemia and non-Hodgkin lymphomas, including Burkitt's lymphoma, unspecified lymphoma, and hairy cell leukaemia (I(a), I(b), II(b), II(c), II(d), plus ICD-O M code 9940/3); (b) all other and unspecified leukaemias (I(c), I(d), I(e) except ICD-O M code 
9940/3); (c) Hodgkin's disease (II(a)); (d) brain and spinal tumours, including non-malignant tumours (III(a) to III(e)); and (e) all other malignant diseases (II(f), IV to XII).

Diagnostic group (a) was chosen in the light of discussions in the report on Dounreay (paras 2.27$2.30)^{2}$ and of the conclusion of the working group that acute lymphoblastic leukaemia could be adequately distinguished from other leukaemia in our data. Chronic lymphocytic leukaemia never occurs in childhood, and so in children lymphoid leukaemia is equivalent to acute lymphoblastic leukaemia. Hairy cell leukaemia is now regarded as a variant of chronic lymphocytic leukaemia and has been grouped with it. ${ }^{9}$

Langerhans cell histiocytosis (histiocytosis $\mathrm{X}$ ) was not included in the analyses as this group of diseases is not now regarded as neoplastic.

\section{AREAS}

The areas used throughout the study (figure) were (a) Seascale ward; (b) Allerdale and Copeland county districts (without Seascale), the two county districts nearest to Sellafield; (c) Cumbria county (without Allerdale and Copeland). All boundaries came into force with the local government reorganisation of 1974 . Cases were assigned to areas according to their residence address at diagnosis as defined for the national cancer registration scheme. ${ }^{10}$

\section{CALENDAR PERIODS}

Data are presented for 1963-83 and for 1984-90. The period 1984-90 does not overlap with any of the analyses covered in the Black report.

\section{CASE ASCERTAINMENT}

For the analyses of childhood cancers including leukaemias - that is, those diagnosed in children aged 0-14 years-data were obtained from the National Registry of Childhood Tumours at the Childhood Cancer Research Group. ${ }^{11}$ Cases are ascertained from cancer registries, the Northern Region Children's Malignant Disease Registry (for 1968 onwards), ${ }^{12}$ the Manchester Children's Tumour Registry (for cases occurring before 1974 in the area now called South Cumbria), ${ }^{13}$ death certificates, entries to the Medical Research Council leukaemia trials (1970 onwards), and the register of the United Kingdom Children's Cancer Study Group (1977 onwards). Details of the methods of ascertainment of cases and verification of diagnostic

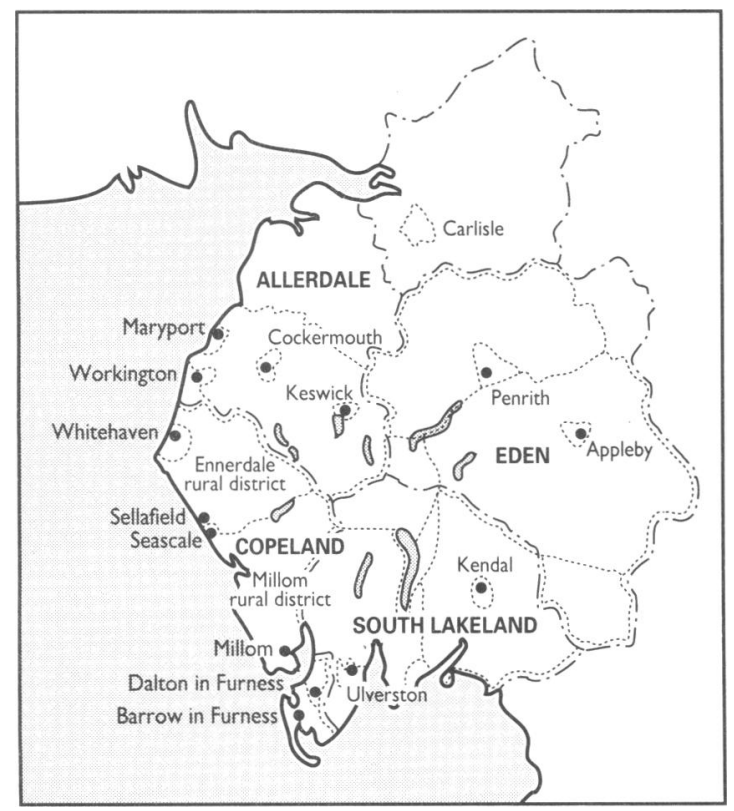

County of Cumbria showing districts before (-.--) and after (-.-.-.) its creation in 1974 (based on figure 2.3 of Black report') and other information have been published elsewhere." For the areas in our study there was a high degree of completeness of ascertainment from 1968 onwards for children aged $0-14$ because these areas are included in the data collected prospectively for the Northern Region Children's Malignant Disease Registry and all these cases were included in the National Registry of Childhood Tumours.

The analyses for people aged 15-24 were based mainly on data from the Northern Region Children's Malignant Disease Registry, which originally covered only children aged $0-14$ years but was extended, as a result of the recommendations of the Black Advisory Group, to people aged 15-24. For 1969-83 registrations at age 15-24 were obtained from the Northern Region Cancer Registry and (for 1969-73 in what is now South Cumbria) the North Western Regional Cancer Registry; in general, no further effort was made to ascertain cases.

Ascertainment through regional cancer registries may not be complete, ${ }^{13}$ and so a special search of hospital and pathology department records was made to ascertain any cases of leukaemia or lymphoma in Allerdale and Copeland for 1969-83 that might not previously have been registered. This resulted in the inclusion of a further four cases in addition to the 27 previously registered. From 1984 onwards cases have been ascertained directly from hospitals throughout the Northern region. Cumbria has been included in the Leukaemia Research Fund data collection study' since it began in 1984. The data collection study also ascertains cases of leukaemia and lymphoma directly from diagnostic sources within hospitals in its study areas, and these are crosschecked with cancer registration records; ascertainment for these diagnostic groups is believed to be virtually complete. For $1984-90$ a comparison between the Northern region's children's register and the data collection study found no additional cases for Allerdale and Copeland, but for the rest of Cumbria seven were added to the register.

Among people aged 25-74 the only analyses in our paper are of leukaemia and lymphoma for 1984-90, using data derived from the data collection study.

\section{POPULATION DATA}

For the calculation of incidences we needed population estimates for five year age groups for each of the years 1963-90. Census data and estimates from the Office of Population Censuses and Surveys were used wherever these were available. For Seascale in 1986 estimates from CACI Ltd were used. For other years estimates were made by linear interpolation, a proportionate adjustment being made if the total of the estimates so obtained for individual age groups did not agree with the independent estimate from the Office of Population Censuses and Surveys for all ages taken together.

\section{INCIDENCE}

Incidences were expressed as annual rates per million population. For ages $0-14$ and 15-24 age standardised rates were calculated as simple averages of the age specific rates for the five year age groups they contained. Standardised registration ratios were calculated by expressing the observed number of cases as a percentage of the expected number, the expected number being calculated by applying the national age specific rates for each five year age group to the number of people in the population being considered.

\section{COMPARISONS WITH NATIONAL DATA}

On the one hand, the most obviously appropriate analyses of the incidences are comparisons of Seascale with the rest of Copeland plus Allerdale and of each of these areas with the rest of Cumbria, but such 
TABLE I-Summary of population estimates for areas within Cumbria

\begin{tabular}{cccc}
\hline & \multicolumn{4}{c}{ Age (years) } \\
\cline { 2 - 4 } Year & $0-14$ & $15-24$ & $25-74$ \\
\hline \multicolumn{4}{c}{ Seascale } \\
$1961^{\star}$ & 606 & 176 & - \\
$1966 \dagger$ & 604 & 218 & - \\
$1971^{\star}$ & 602 & 259 & - \\
$1976 \dagger$ & 506 & 299 & - \\
$1981^{\star}$ & 411 & 339 & - \\
$1986 \ddagger$ & 320 & 291 & 1126 \\
$1990 \dagger$ & 302 & 234 & 1129 \\
Copeland and Allerdale minus \\
Seascale \\
$1961^{\star}$ & 41990 & 21852 & - \\
$1966 \dagger$ & 41718 & 23215 & - \\
$1971 \|$ & 39898 & 23441 & - \\
$1976 \|$ & 37694 & 24101 & - \\
$1981 \|$ & 34224 & 25719 & - \\
$1986 \|$ & 30885 & 25514 & 98988 \\
$1990 \|$ & 30717 & 22836 & 102614 \\
4 \\
$1961^{\star}$ & Rest of Cumbria & \\
$1966 \dagger$ & 69227 & 37794 & - \\
$1971 \|$ & 70400 & 42200 & - \\
$1976 \|$ & 69200 & 42400 & - \\
$1981 \|$ & 61049 & 46624 & - \\
$1986 \|$ & 56721 & 49464 & 189621 \\
$1990 \|$ & 55926 & 44855 & 196978 \\
\hline & \multicolumn{4}{c}{} \\
\hline
\end{tabular}

*Census.

†Interpolated.

$¥$ CACI.

Office of Population Censuses

and Surveys. comparisons are based on comparatively small numbers. On the other hand, comparisons with national data may be less relevant in that there may be broad geographical variations either in incidence or in case ascertainment that would make it difficult to determine whether an increase in Seascale or Allerdale and Copeland was a local effect (and hence possibly related to Sellafield) or whether it affected the whole of Cumbria. By calculating rates for each of these areas it is possible to examine the geographical extent of any apparently local increase.

National data of the same quality used for the present analyses were not always available, though even $20 \%$ under-registration, which is unlikely, would not have affected the conclusions of this report. We compared the incidence in the study areas with national data using the following sources: for childhood cancer, data from the National Registry of Childhood Tumours for 1969-87; for young people aged 15-24, cancer registration statistics for England and Wales for 1971-86, though these data were not subjected to the review processes carried out for the specialist registries; for leukaemias and lymphomas in those aged 25-74, data from the data collection study covering about one third of the population of England and Wales.'

\section{Results}

POPULATION ESTIMATES

Estimates for five year age groups and the calendar years 1963-90 are summarised in table I.

\section{NATIONAL DATA ON CANCER REGISTRATIONS}

Age standardised annual incidence of specific cancers for England and Wales is given in table II.

CASES OF CANCER IN YOUNG PEOPLE IN SEASCALE SINCE 1953

Table III lists all cases of cancer diagnosed during

TABLE II-Age standardised annual incidence of specific cancers per million, England and Wales

Age 0-14 yearst Age 15-24 yearsł

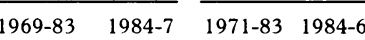

Lymphoid leukaemia and

non-Hodgkin lymphomas

Other leukaemias

Hodgkin's disease

Brain tumours (including benign)

Other malignant tumours

All registrations

$\begin{array}{rrrr}35.5 & 39 \cdot 6 & 18 \cdot 8 & 19 \cdot 8 \\ 8.5 & 7 \cdot 6 & 11 \cdot 1 & 9 \cdot 0 \\ 4 \cdot 5 & 5 \cdot 5 & 33 \cdot 5 & 31 \cdot 1 \\ 25 \cdot 5 & 27 \cdot 6 & 27.7 & 24 \cdot 4 \\ 35 \cdot 5 & 41 \cdot 1 & 93 \cdot 1 & 90 \cdot 6 \\ 109 \cdot 4 & 121.3 & 183 \cdot 8 & 174.9\end{array}$

*Calculated for populations with equal numbers in each five year age group for the age range shown

† National Registry of Childhood Tumours.

$\ddagger$ Cancer registration statistics for England and Wales.

TABLE III-Details of cases of cancer occurring among people aged 0-24 years who were resident in Seascale at diagnosis, 1953 onwards

\begin{tabular}{|c|c|c|c|c|c|c|c|}
\hline $\begin{array}{l}\text { Case } \\
\text { No }\end{array}$ & $\begin{array}{c}\text { Year of } \\
\text { birth }\end{array}$ & $\begin{array}{c}\text { Year of } \\
\text { diagnosis }\end{array}$ & $\begin{array}{c}\text { Age } \\
\text { (years) }\end{array}$ & Sex & Diagnosis & $\begin{array}{c}\text { Included } \\
\text { in present } \\
\text { analysis }\end{array}$ & $\begin{array}{l}\text { Reference } \\
\text { No in } \\
\text { Black report }\end{array}$ \\
\hline 1 & 1948 & 1954 & 6 & $\mathbf{M}$ & Neuroblastoma & No & 22 \\
\hline 2 & 1947 & 1955 & 7 & $\mathrm{~F}$ & Acute lymphoblastic leukaemia & No & 1 \\
\hline 3 & 1957 & 1960 & 2 & $\mathrm{M}$ & Acute myeloid leukaemia & No & 3 \\
\hline 4 & 1957 & 1968 & 11 & $\mathrm{M}$ & Acute lymphoblastic leukaemia & Yes & 2 \\
\hline 5 & 1964 & 1968 & 4 & $\mathrm{M}$ & Acute lymphoblastic leukaemia & Yes & 5 \\
\hline 6 & 1968 & 1971 & 2 & $\mathrm{~F}$ & Acute lymphoblastic leukaemia & Yes & 6 \\
\hline 7 & 1960 & 1975 & 15 & $\mathrm{~F}$ & Rhabdomyosarcoma ${ }^{\star}$ & Yes & 26 \\
\hline 8 & 1974 & 1979 & 5 & $\mathrm{~F}$ & Acute lymphoblastic leukaemia & Yes & 7 \\
\hline 9 & 1974 & 1983 & 9 & $\mathrm{M}$ & Non-Hodgkin lymphoma & Yes & 16 \\
\hline 10 & 1982 & 1984 & 1 & $\mathrm{~F}$ & Non-Hodgkin lymphoma & Yes & 17 \\
\hline 11 & 1966 & 1985 & 18 & $\mathrm{M}$ & Pinealoma & Yes & - \\
\hline 12 & 1965 & 1988 & 23 & $\mathrm{~F}$ & Non-Hodgkin lymphoma & Yes & - \\
\hline 13 & 1970 & 1988 & 17 & $\mathrm{~F}$ & Hodgkin's disease & Yes & - \\
\hline 14 & 1975 & 1991 & 16 & $\mathrm{M}$ & Acute lymphoblastic leukaemia & No & - \\
\hline 15 & 1958 & 1978 & 20 & $\mathrm{M}$ & Chronic myeloid leukaemia & No & $4^{\star \star}$ \\
\hline
\end{tabular}

* Previously described as retroperitoneal sarcoma.

$\star \star$ This patient also had an address in another region of England where he was resident at the time of diagnosis, and he is therefore excluded from all the analyses.
TABLE IV-Age standardised annual incidence of specific cancers per million children aged 0-14 years in specified areas of Cumbria

\begin{tabular}{|c|c|c|c|c|c|c|}
\hline \multirow[b]{2}{*}{ Year } & \multirow{2}{*}{\multicolumn{2}{|c|}{$\begin{array}{cc} & \begin{array}{c}\text { Seascale } \\
\text { ward }\end{array} \\
& \begin{array}{c}\text { Age } \\
\text { standardised } \\
\text { Nate }\end{array} \\
\text { No } & \text { rate }\end{array}$}} & \multirow{2}{*}{\multicolumn{2}{|c|}{$\begin{array}{c}\begin{array}{c}\text { Allerdale and } \\
\text { Copeland minus } \\
\text { Seascale ward }\end{array} \\
\begin{array}{c}\text { Age } \\
\text { standardised } \\
\text { No }\end{array} \\
\text { rate }\end{array}$}} & \multirow{2}{*}{\multicolumn{2}{|c|}{$\begin{array}{l}\text { Rest of Cumbria } \\
\text { No } \begin{array}{c}\text { Age } \\
\text { standardised } \\
\text { rate }\end{array}\end{array}$}} \\
\hline & & & & & & \\
\hline \multicolumn{7}{|c|}{ Lymphoid leukaemia and non-Hodgkin lymphomas } \\
\hline $1963-83$ & 5 & $459 \cdot 1$ & 19 & $24 \cdot 2$ & 50 & $35 \cdot 8$ \\
\hline $1984-90$ & 1 & $511 \cdot 2$ & 7 & $32 \cdot 5$ & 26 & $66 \cdot 4$ \\
\hline $1963-90$ & 6 & $470 \cdot 7$ & 26 & $26 \cdot 0$ & 76 & $42 \cdot 5$ \\
\hline \multicolumn{7}{|c|}{ Other leukaemias } \\
\hline $1963-83$ & 0 & 0.0 & 7 & $8 \cdot 7$ & 11 & $7 \cdot 8$ \\
\hline $1984-90$ & 0 & $0 \cdot 0$ & 3 & $13 \cdot 8$ & 4 & $10 \cdot 0$ \\
\hline $1963-90$ & 0 & $0 \cdot 0$ & 10 & $9 \cdot 9$ & 15 & $8 \cdot 3$ \\
\hline \multicolumn{7}{|c|}{ Hodgkin's disease } \\
\hline 1963-83 & 0 & $0 \cdot 0$ & 0 & $0 \cdot 0$ & 4 & $2 \cdot 7$ \\
\hline $1984-90$ & 0 & $0 \cdot 0$ & 1 & $4 \cdot 5$ & 4 & $9 \cdot 7$ \\
\hline $1963-90$ & 0 & 0.0 & 1 & 0.9 & 8 & $4 \cdot 2$ \\
\hline \multicolumn{7}{|c|}{ Brain tumours (including benign) } \\
\hline $1963-83$ & 0 & 0.0 & 21 & $26 \cdot 2$ & 44 & $31 \cdot 1$ \\
\hline $1984-90$ & 0 & $0 \cdot 0$ & 4 & $18 \cdot 6$ & 6 & $15 \cdot 2$ \\
\hline $1963-90$ & 0 & $0 \cdot 0$ & 25 & $24 \cdot 5$ & 50 & $27 \cdot 6$ \\
\hline \multicolumn{7}{|c|}{ Other malignant tumours } \\
\hline $1963-83$ & 0 & $0 \cdot 0$ & 31 & $39 \cdot 3$ & 43 & $30 \cdot 8$ \\
\hline $1984-90$ & 0 & $0 \cdot 0$ & 12 & $55 \cdot 8$ & 14 & $35 \cdot 9$ \\
\hline $1963-90$ & 0 & 0.0 & 43 & $42 \cdot 8$ & 57 & $32 \cdot 0$ \\
\hline \multicolumn{7}{|c|}{ All registrations } \\
\hline $1963-83$ & 5 & $459 \cdot 1$ & 78 & $98 \cdot 4$ & 152 & $108 \cdot 2$ \\
\hline $1984-90$ & 1 & $511 \cdot 2$ & 27 & $125 \cdot 2$ & 54 & $137 \cdot 1$ \\
\hline $1963-90$ & 6 & $470 \cdot 7$ & 105 & $104 \cdot 1$ & 206 & $114 \cdot 7$ \\
\hline
\end{tabular}

1953-91 in people aged 0-24 in Seascale. We checked as far as possible the information for the cases listed in tables 2.1 to 2.4 of the Black report; in table III cross references are given to the cases listed in these tables of the Black report and, when necessary, the information has been corrected. Ten cases diagnosed during 1963-90 (cases 4-13) were included in our analyses. One from the most recent period, 1984-90 (case 10 in table III), was included in the Black report but with the year of diagnosis given wrongly as 1983 instead of 1984. This case was notified to the Black Advisory Group during the course of its investigation and does not appear in any of the analyses in its report. We therefore included the case in our analysis for the postBlack period 1984-90 as this information should be regarded as testing rather than generating the Seascale hypothesis. One further patient (case 15 in table III) had a second address in another part of Britain, to which he should correctly be allocated under the rules followed by the national cancer registration scheme; he has therefore been excluded from the analyses. Four other cases in table III were excluded from our analyses because they fell outside the period covered: cases 1-3 occurred before complete registration data were available, and case 14 occurred in 1991 after the decision had been taken to make 1990 the final year of the analysis.

\section{CANCER INCIDENCE AT AGES 0-14 YEARS, 1963-90}

Table IV shows the numbers of cases of cancer together with the age standardised rates in children aged 0-14 years for each diagnostic group in the three study areas during 1963-83 and 1984-90. The rates of malignant disease and specifically of lymphoid leukaemia and non-Hodgkin lymphomas for children in Seascale were substantially higher than those for the remainder of Copeland and Allerdale, Cumbria, and England and Wales. In Allerdale and Copeland (excluding Seascale) the rates for lymphoid leukaemia and non-Hodgkin lymphomas were lower than those for other parts of Cumbria and for England and Wales. In the remainder of Cumbria the rates were higher than those for England and Wales.

Thus there is no evidence over the period from 1963 onwards that the excess found in Seascale extends to a wider area around Sellafield, though for the most recent period there was a slight increase in the incidence 
of lymphoid leukaemia and non-Hodgkin lymphomas in the rest of Cumbria, particularly among children aged $0-4$ years.

CANCER INCIDENCE AT AGES 15-24 YEARS, 1969-90

Results, mainly from data from the Northern Region Children's Malignant Disease Registry, for those aged 15-24 for 1969-90 are given in table V. In Seascale there were four cases, of which three were diagnosed during 1984-90 (one non-Hodgkin lymphoma, one Hodgkin's disease, and one pineal tumour). Again this represents a considerable increase over the national rates whether one considers lymphoid leukaemia and non-Hodgkin lymphomas or all malignant disease and for both 1963-90 and 1984-90. In the remainder of Copeland and Allerdale and in the rest of Cumbria the rates were unremarkable.

LEUKAEMIA AND LYMPHOMAS AT AGES 25-74 YEARS, 1984-90

Table VI shows the numbers of cases of leukaemia and lymphomas for 10 year age groups in the age range 25-74, together with age specific and overall incidence rates, in the three study areas during 1984-90. In Seascale there were two cases of non-Hodgkin lymphoma, both occurring at ages 55-64. On the basis of the national rates in the data collection study one case would be expected. Thus the excess found among young people does not extend to the older age groups.

TABLE V-Age standardised annual incidence of specific cancers per million people aged 15-24 in specified areas of Cumbria

\begin{tabular}{|c|c|c|c|c|c|c|}
\hline \multirow[b]{2}{*}{ Year } & \multirow{2}{*}{\multicolumn{2}{|c|}{$\begin{array}{cc} & \begin{array}{c}\text { Seascale } \\
\text { ward }\end{array} \\
& \begin{array}{c}\text { Age } \\
\text { Ntandardised } \\
\text { No }\end{array} \\
\text { rate }\end{array}$}} & \multirow{2}{*}{\multicolumn{2}{|c|}{$\begin{array}{c}\begin{array}{c}\text { Allerdale and } \\
\text { Copeland minus } \\
\text { Seascale ward }\end{array} \\
\begin{array}{cc}\text { Age } \\
\text { standardised } \\
\text { No }\end{array} \\
\text { rate }\end{array}$}} & \multirow{2}{*}{\multicolumn{2}{|c|}{$\begin{array}{cc}\text { Rest of Cumbria } & \text { Age } \\
\text { No } & \text { standardised } \\
\text { rate }\end{array}$}} \\
\hline & & & & & & \\
\hline \multicolumn{7}{|c|}{ Lymphoid leukaemia and non-Hodgkin lymphomas } \\
\hline $1969-83$ & 0 & 0.0 & 12 & $32 \cdot 4$ & 9 & $14 \cdot 4$ \\
\hline $1984-90$ & 1 & 542.9 & 4 & $22 \cdot 6$ & 4 & 11.9 \\
\hline $1969-90$ & 1 & $192 \cdot 8$ & 16 & $29 \cdot 6$ & 13 & 13.5 \\
\hline \multicolumn{7}{|c|}{ Other leukaemias } \\
\hline $1969-83$ & 0 & $0 \cdot 0$ & 4 & $11 \cdot 2$ & 5 & $7 \cdot 6$ \\
\hline $1984-90$ & 0 & $0 \cdot 0$ & 2 & 11.5 & 3 & $8 \cdot 9$ \\
\hline $1969-90$ & 0 & $0 \cdot 0$ & 6 & $11 \cdot 2$ & 8 & $8 \cdot 1$ \\
\hline \multicolumn{7}{|c|}{ Hodgkin's disease } \\
\hline $1969-83$ & 0 & $0 \cdot 0$ & 15 & $41 \cdot 3$ & 19 & $31 \cdot 1$ \\
\hline $1984-90$ & 1 & $500 \cdot 0$ & 11 & $63 \cdot 2$ & 15 & $44 \cdot 7$ \\
\hline $1969-90$ & 1 & $133 \cdot 0$ & 26 & $48 \cdot 3$ & 34 & $35 \cdot 2$ \\
\hline \multicolumn{7}{|c|}{ Brain tumours (including benign) } \\
\hline 1969-83 & 0 & $0 \cdot 0$ & 8 & 21.7 & 12 & $18 \cdot 4$ \\
\hline $1984-90$ & 1 & $500 \cdot 0$ & 6 & $34 \cdot 6$ & 2 & $6 \cdot 0$ \\
\hline $1969-90$ & $i$ & 133.0 & 14 & 25.9 & 14 & $14 \cdot 2$ \\
\hline \multicolumn{7}{|c|}{ Other malignant tumours } \\
\hline $1969-83$ & 1 & $181 \cdot 2$ & 24 & $65 \cdot 8$ & 45 & $70 \cdot 1$ \\
\hline $1984-90$ & 0 & 0.0 & 8 & $46 \cdot 2$ & 18 & $53 \cdot 4$ \\
\hline $1969-90$ & 1 & $133 \cdot 0$ & 32 & $59 \cdot 4$ & 63 & $64 \cdot 4$ \\
\hline \multicolumn{7}{|c|}{ All registrations } \\
\hline $1969-83$ & 1 & $181 \cdot 2$ & 63 & $172 \cdot 3$ & 90 & $141 \cdot 5$ \\
\hline $1984-90$ & 3 & 1542.9 & 31 & $178 \cdot 2$ & 42 & 124.8 \\
\hline $1969-90$ & 4 & 591.8 & 94 & 174.4 & 132 & $135 \cdot 3$ \\
\hline
\end{tabular}

TABLE VII-Observed numbers of cases at ages 0-24 years in Seascale, 1963-90, and Poisson probability of observed or greater number of cases *

\begin{tabular}{llll}
\hline & $\begin{array}{c}\text { Lymphoid } \\
\text { leukaemia } \\
\text { and non- } \\
\begin{array}{c}\text { Hodgkin } \\
\text { lymphomas }\end{array}\end{array}$ & $\begin{array}{c}\text { Other } \\
\text { cancers }\end{array}$ & $\begin{array}{c}\text { All } \\
\text { malignant }\end{array}$ \\
\hline $\begin{array}{l}\text { 1963-83: } \\
\text { No of cases in Seascale }\end{array}$ & 5 & 1 & 6 \\
$\begin{array}{l}\text { Probability of obtaining at least } \\
\text { this No of cases }\end{array}$ & 0.000161 & 0.816 & 0.0242 \\
$\begin{array}{l}\text { 1984-90: } \\
\text { No of cases in Seascale }\end{array}$ & 2 & 2 & 4 \\
$\begin{array}{l}\text { Probability of obtaining at least } \\
\text { this No of cases }\end{array}$ & 0.00702 & 0.0831 & 0.00335 \\
\hline
\end{tabular}

${ }^{\star}$ Calculated from estimates of incidence in England and Wales as given in table II.

RATES OF MALIGNANT DISEASE IN SEASCALE AT AGES

0-24 YEARS, 1963-83 AND 1984-90

The rates for Seascale were based on very small numbers. The method used to carry out a formal analysis of the hypothesis that there is no raised incidence of cancer among young persons aged 0-24 was the same as that in the Black report and was based on a comparison with the national rates for England and Wales summarised in table II. It is clear from a comparison of the rates in tables II, IV, and V that much the same results would be obtained if the rates for Cumbria or for Allerdale and Copeland were used. Expected numbers of cases are calculated on the assumption that the true rates are the same as those for England and Wales. In table VII we compared the observed numbers of cases with those expected for lymphoid leukaemia and non-Hodgkin lymphomas, for all other cancers, and for all cancers combined separately for 1963-83 and 1984-90.

In 1963-83 a total of six cases, of which five were lymphoid leukaemia and non-Hodgkin lymphomas, occurred. The expected number of cases of lymphoid leukaemia and non-Hodgkin lymphomas on the basis of national rates is 0.49 (standardised registration ratio=1015); the expected number for all malignant disease is $2 \cdot 18$ (standardised registration ratio $=275$ ). The probabilities of such high values occurring by chance are respectively $\mathrm{p}=0.00016$ and $\mathrm{p}=0.024$. These probabilities are low and support the findings of the Black report, though they exaggerate the significance of the findings because there was no prior hypothesis, formulated independently of the observed data, in determining the diagnostic groups, age groups, periods, or area to be studied.

This criticism does not extend to analyses of subsequent periods. In table VII we analyse also the data for cancer occurring among young people in Seascale during 1984-90, when a total of four cases occurred in those aged 0-24 years. The expected number of cases of lymphoid leukaemia and non-Hodgkin lymphomas in this period and age group is $0 \cdot 12$ (standardised registra-

TABLE VI-Age specific annual incidence of leukaemia and lymphomas per million people aged 25-74 in specified areas of Cumbria, $1984-90$

\begin{tabular}{|c|c|c|c|c|c|c|c|c|c|c|c|c|}
\hline & \multicolumn{12}{|c|}{ Age (years) } \\
\hline & \multicolumn{2}{|c|}{$25-34$} & \multicolumn{2}{|c|}{$35-44$} & \multicolumn{2}{|c|}{$45-54$} & \multicolumn{2}{|c|}{$55-64$} & \multicolumn{2}{|c|}{$65-74$} & \multicolumn{2}{|c|}{$\begin{array}{c}\text { Total } \\
25-74\end{array}$} \\
\hline & No & Rate & No & Rate & No & Rate & No & Rate & No & Rate & No & Rate \\
\hline \multicolumn{13}{|c|}{ Seascale ward } \\
\hline Lymphoid leukaemia and non-Hodgkin lymphomas & 0 & $0 \cdot 0$ & 0 & 0.0 & 0 & $0 \cdot 0$ & 2 & $1176 \cdot 5$ & 0 & 0.0 & 2 & $252 \cdot 0$ \\
\hline Other leukaemias & 0 & $0 \cdot 0$ & 0 & $0 \cdot 0$ & 0 & 0.0 & 0 & $0 \cdot 0$ & 0 & 0.0 & 0 & $0 \cdot 0$ \\
\hline Hodgkin's disease & 0 & $0 \cdot 0$ & 0 & $0 \cdot 0$ & 0 & 0.0 & 0 & 0.0 & 0 & 0.0 & 0 & 0.0 \\
\hline \multicolumn{13}{|c|}{ Allerdale and Copeland minus Seascale ward } \\
\hline Lymphoid leukaemia and non-Hodgkin lymphomas & 4 & $23 \cdot 5$ & 4 & $24 \cdot 9$ & 17 & $126 \cdot 9$ & 23 & $175 \cdot 7$ & 46 & $442 \cdot 8$ & 94 & $134 \cdot 3$ \\
\hline Other leukaemias & 1 & 5.9 & 2 & $12 \cdot 4$ & 6 & $44 \cdot 8$ & 16 & $122 \cdot 2$ & 18 & $173 \cdot 3$ & 43 & $61 \cdot 4$ \\
\hline Hodgkin's disease & 2 & $11 \cdot 7$ & 4 & $24 \cdot 9$ & 1 & $7 \cdot 5$ & 2 & 15.3 & 4 & 38.5 & 13 & $18 \cdot 6$ \\
\hline \multicolumn{13}{|c|}{ Rest of Cumbria } \\
\hline Lymphoid leukaemia and non-Hodgkin lymphomas & 5 & $16 \cdot 0$ & 21 & $69 \cdot 8$ & 28 & $111 \cdot 0$ & 62 & 241.5 & 105 & $482 \cdot 5$ & 221 & $165 \cdot 0$ \\
\hline Other leukaemias & 6 & $19 \cdot 2$ & 8 & $26 \cdot 6$ & 6 & 23.8 & 13 & $50 \cdot 6$ & 31 & $142 \cdot 4$ & 64 & $47 \cdot 8$ \\
\hline Hodgkin's disease & 4 & $12 \cdot 8$ & 10 & $33 \cdot 2$ & 6 & $23 \cdot 8$ & 11 & $42 \cdot 8$ & 6 & $27 \cdot 6$ & 37 & $27 \cdot 6$ \\
\hline
\end{tabular}


tion ratio $=1620$ ). For all diagnostic categories taken together the expected number is 0.60 (standardised registration ratio $=667$ ). Whether we consider just the two cases of lymphoid leukaemia and non-Hodgkin lymphomas or the total of four cases there was a significant $(p=0.0070$ and $p=0.0034$, respectively) excess of cases in Seascale in this period.

\section{Discussion}

Two principal questions are considered in this paper. Firstly, do the findings of the Black report relating to the period up to and including 1983 remain unchanged now that more comprehensive data sets and analyses are available? Secondly, did the excess incidence of childhood leukaemia in Seascale found in the various analyses summarised in the Black report persist in later years? The present report covers the periods $1963-90$ for children aged 0-14 years, $1969-90$ for people aged 15-24, and 1984-90 for leukaemia and lymphomas in adults. As explained in the introduction, the diagnostic groups, age groups, calendar periods, and areas to be analysed were agreed in advance of the analyses being carried out.

The conclusions of the Black report are confirmed insofar as they relate to malignant disease occurring in young people between 1963 and 1983; on the basis of the six cases included in table III we conclude that the excess in Seascale is unlikely to have arisen by chance (table VII). All of the six cases are included in the report by Craft et al. ${ }^{1+}$ We omitted from these analyses case 15 in table III because this person had an address in another part of Britain which was regarded as his area of residence for the purposes of the national cancer registration scheme. "Inclusion of this case would have strengthened our conclusions about the period 1963-83.

For the period before 1984 our analyses rely on much the same evidence as the Black report, though more complete registration data are now available. There is, however, no way of overcoming the objection that analyses of Seascale data for this period are not amenable to any rigorous statistical evaluation because the area, age group, and types of disease to be studied were selected as a result of the observed clustering of cases.

This criticism cannot be applied to the results for 1984-90. Even the case from this period that was included in the Black report (with the year of diagnosis wrongly given as 1983 rather than 1984) was diagnosed after concern had been raised about the high incidence in Seascale. For those aged 0-24 there is an excess of malignant disease that is highly unlikely to have arisen by chance (table VII). These more recent data therefore strengthen the suggestion that there is an increased incidence in Seascale among those aged 0-24 years, but whereas the original findings related mainly to lymphoid leukaemia in those aged $0-14$ years, there were no leukaemias and only one case below age 15 during 1984-90. Of the four cases found in this period two had non-Hodgkin lymphomas, one Hodgkin's disease, and one a pineal tumour; the excess is mainly attributable to non-Hodgkin lymphomas. We have excluded from these analyses case 14 in table III because this case occurred beyond the period specified in planning the analysis (see introduction). The occurrence of this case does, however, strengthen the conclusion that there is an excess of lymphoid leukaemia and non-Hodgkin lymphomas among those aged 0-24 years in Seascale. As regards other cancers in this age group, there is a small, non-significant excess during 1984-90 but no overall excess if the whole period 1963-90 is considered.

There is no evidence that the raised incidence in Seascale extends to the two county districts nearest to Sellafield or to Cumbria generally. There was an apparently raised incidence of lymphoid leukaemia and non-Hodgkin lymphomas in the rest of Cumbria in 1984-90 among those aged 0-4 years, but this is based on only 13 cases and is difficult to interpret. Birth records have been obtained for the 42 children with cancer diagnosed up to the age of 4 years throughout Cumbria during 1984-90 in order to investigate the possibility that some of these children had been born in Seascale and then moved, but in fact only the child resident in Seascale at diagnosis was also domiciled there at birth.

\section{EXPLANATIONS FOR OUR FINDINGS}

We consider some of the main hypotheses that might account for our findings.

Firstly, the results may simply be due to chance since a search for clusters is likely to reveal some spatial aggregations of cases even if there is no causal explanation: this is particularly true if the age groups, areas, calendar periods, and diagnostic groups to be studied are not specified in advance. When claims were originally made concerning a cluster at Seascale it seemed quite possible that this was the explanation. The accumulation of further data since the original reports and the analysis in table VII suggest that this is not the correct explanation.

Secondly, the most obvious suggestion is that the cases are caused by the direct effects of environmental radiation on the child or fetus. The results of calculations based on estimates of environmental discharges and on modelling of risks attributable to such radiation suggest that the doses delivered to the child or fetus were far too low to explain the cluster unless either the discharges were considerably underestimated or the assumptions made in computing the risks were grossly incorrect. ${ }^{15}$

Thirdly, Gardner et al, in their case-control study of leukaemia and lymphoma diagnosed during 1950-85 among young people in West Cumbria, concluded that the excess occurred among children whose fathers had high levels of exposure to radiation before the child was conceived, and perhaps particularly in the preceding six months; they suggested that some cases were the result of paternal germ cell mutations, and that this could explain the excess in this geographical area. Again, the level of risk implied by this explanation seems inconsistent with the dosimetry and previous estimates of genetic risk. The measured dose of external radiation might be a surrogate measure for internal exposure to radionuclides or to chemicals; such alternative explanations are still open to the objection that there are no generally accepted data on humans to support this. Our analysis includes the geographical area covered by Gardner et al but follows it too closely in time to provide data to test their findings; only cases $12-14$ in table III (one nonHodgkin lymphoma, one leukaemia, one Hodgkin's disease) were diagnosed after the period covered by the Gardner study and moreover all three were conceived before the parents moved to Seascale.

The only published study that can be directly compared with the Gardner report is that by McLaughlin et al on workers at nuclear facilities in Ontario; they found no increased risk of leukaemia in the children of fathers working in these facilities. ${ }^{16}$ In particular, although the numbers of cases and the prevalence of exposures in the highest dose categories considered by Gardner $e t$ al were similar for the control fathers in the two studies, the Ontario study found no evidence of a risk associated with such doses. Differences between the studies include the fact that Canadian workers "receive a substantial proportion $(20-40 \%)$ of their total exposure as an internal dose (largely due to tritium)," that workers in Ontario did not have the types of chemical exposure received by the 
Sellafield workers, and that some of the control fathers with high doses were uranium miners.

Little is known about risk factors for childhood leukaemias and lymphomas. In a series of papers Stewart and colleagues have shown a significant association, now widely accepted as causal, between obstetric radiography and childhood leukaemia and other cancers. ${ }^{17}$ For children born in the late 1950 s and early 1960 s this could have accounted for perhaps $5 \%$ of cases; as Gardner et al showed it does not explain the increased incidence in Seascale. ${ }^{7}$ Kinlen et al have carried out a number of analyses relating to areas in which there has been increased population mixing and have found an increased incidence of childhood leukaemia in some of these areas. ${ }^{1819}$ They attribute this to an increased likelihood of exposure to a leukaemogenic virus or viruses. The high incidence in Seascale occurred over an extended period, and we are not sure whether this could be explained by Kinlen's hypothesis. A number of studies (see, for example, Draper et $a l^{20}$ ) have suggested that childhood leukaemia is more common among higher socioeconomic groups, and it has also been suggested that the risk of childhood acute lymphoblastic leukaemia is doubled in isolated towns and villages, ${ }^{21}$ but the excess in Seascale is too large to be accounted for in these ways.

In conclusion, we confirm that there is good evidence for an increased incidence of lymphoid leukaemia and non-Hodgkin lymphomas among young people in Seascale, though we are unable to identify the cause of this increase; nor can we say that our data and analyses either support or detract from the conclusions of Gardner et al.

We thank the Office of Population Censuses and Surveys, regional cancer registries, specialised childhood tumour registries, and members of the UK Children's Cancer Study Group for providing copies of notifications of childhood cancer cases, and haematologists in Whitehaven and Carlisle hospitals for information on leukaemia and lymphoma cases. We thank many colleagues, particularly Jim Miller, Shirley Wilson, and Lorna More; and the registry and computing staff at the Childhood Cancer Research Group for help with data collection; and Sue Medhurst for secretarial help. Support for this work was received from the Department of Health, the Scottish Home and Health Department, the Leukaemia Research Fund, and the North of England Children's Cancer Research Fund.

1 Black D. Investigation of the possible increased incidence of cancer in West Cumbria. Report of the Independent Advisory Group. London: HMSO, 1984.
2 Committee on the Medical Aspects of Radiation in the Environment (COMARE). Second report. Investigation of the possible increased incidence of leukaemia in young people near the Dounreay nuclear establishment, Caithness, Scotland. London: HMSO, 1988.

3 Committee on the Medical Aspects of Radiation in the Environment (COMARE). Third report. Report of the incidence of childhood cancer in the West Bershire and repon. Repon of the incidence of childhood cancer in the West Berkshire and North Hampshire area, in which are situated the Atomic Weapons Research Establishment, Aldermast Burghfield. London: HMSO, 1989.

4 Cook-Mozaffari PJ, Darby SC, Doll R, Forman D, Hermon C, Pike MC, Vincent T. Geographical variation in mortality from leukaemia and othe cancers in England and $W$ ales in relation to proximity to nuclear installations, 1969-78. Br J Cancer 1989;59:476-85.

5 Gardner MJ, Hall AJ, Downes S, Terrell JD. Follow up study of children born to mothers resident in Seascale, West Cumbria (birth cohort). BM 1987;295:822-7.

6 Gardner MJ, Hall AJ, Downes S, Terrell JD. Follow up study of children born elsewhere but attending schools in Seascale, West Cumbria (schools cohort) $B M 71987 ; 295: 819-22$.

7 Gardner MJ, Snee MP, Hall AJ, Powell CA, Downes S, Terrell JD. Results of case-control study of leukaemia and lymphoma among young people near Sellafield nuclear plant in West Cumbria. BMJ 1990;300:423-9.

8 Birch JM, Marsden HB. A classification scheme for childhood cancer. In $\mathcal{F}$ Cancer 1987;40:620-4.

9 Cartwright RA, Alexander FE, McKinney PA, Ricketts TJ. Leukaemia and lymphoma. An atlas of distribution within areas of England and Wales 1984-88. London: Leukaemia Research Fund, 1990

10 Swerdlow AJ. Cancer registration in England and Wales: some aspects relevan to interpretation of the data. $\mathcal{F}$ Statist Soc $A$ 1986;149:146-60.

11 Stiller CA, O'Connor CM, Vincent TJ, Draper GJ. The national registry of childhood tumours and the leukaemia/lymphoma data for 1966-83. In Draper G, ed. The geographical epidemiology of childhood leukaemia and nonHodgkin lymphomas in Great Britain 1966-83. London: HMSO, 1991:7-16. (OPCS Studies in Medical and Population Subjects No 53.)

12 Craft AW, Amineddine HA, Scott JES, Wagget J. The Northern Region Children's Malignant Disease Registry 1968-82: incidence and survival. Brf Cancer 1987;56:853-8.

13 Birch JM. United Kingdom-Manchester Children's Tumour Registry 1954-1970 and 1971-1983. In: Parkin DM, Stiller CH, Draper GJ, Bieber CA, Terracini B, Young JL, eds. International incidence of childhood cancer. CA, Terracini B, Young JL, eds. International incidence of childhood

14 Craft AW, Parker L, Openshaw S, Chariton M, Newell J, Birch JM, Blair V. Cancer in young people in the North of England 1968-85. Analysis by census wards. $\mathcal{f}$ Epidemiol Community Health (in press).

15 Committee on Medical Aspects of Radiation in the Environment (COMARE) The implications of the new data on the releases from Sellafield in the 1950s for the conclusions of the Report on the Investigation of the Possible Increased Incidence of Cancer in West Cumbria. London: HMSO, 1986.

16 McLaughlin JR, Anderson TW, Clarke EA, King W. Occupational exposure of fathers to ionising radiation and the risk of leukaemia in offspring- a case-control study. Ottawa: Atomic Energy Control Board, 1992.

17 Bithell JF, Stewart AM. Pre-natal irradiation and childhood malignancy: a review of British data from the Oxford Survey. Br f Cancer 1975;31:271-87.

18 Kinlen LJ, Clarke K, Hudson C. Evidence from population mixing in British new towns 1946-85 of an infective basis of childhood leukaemia. Lancet new towns 1990;336:577-82.

19 Kinlen LJ, Hudson C. Childhood leukaemia and poliomyelitis in relation to military encampments in England and Wales in the period of national military encampments in England and Wales in
military service, 1950-63. BMF 1991;303:1357-62.

20 Draper GJ, Vincent TJ, O'Connor CM, Stiller CA. Socio-economic factors and variations in incidence rates between country districts. In: Draper G, ed. The geographical epidemiology of childhood leukaemia and non-Hodgkin lymphomas in Great Britain 1966-83. London: HMSO, 1991:37-45. (OPCS Studies in Medical and Population Subjects No 53.)

21 Alexander FE, McKinney PA, Ricketts TJ, Cartwright RA. Community lifestyle characteristics and risk of acute lymphoblastic leukaemia in children. Lancet 1990;336:1461-5.

(Accepted 27 November 1992)

\section{ONE HUNDRED YEARS AGO}

\section{ROSSINI'S MALADY.}

The French and Italian medical press have recently taken much interest in the life and ailments of the great composer. The question of special import is: Was Rossini neurasthenic? Two facts are certain about his career. In the first place, he overworked himself. Within nineteen years he wrote thirty-six operas. This implies not only great mental work but also severe anxiety, due to thirst for public favour and dread of adverse criticism. At the same time he went freely into society; he was also a very gallant gentleman, and in no way abstemious. Secondly, he suffered from a violent shock when 55 years old, for in 1848 he happened to be at Bologna, where he saw people shot down in the streets. This shock affected him for years. He had inclinations towards suicide; he no longer cared for meals, though his appetite and digestion did not fail, and he could not sleep. He complained of intolerable coldness of the hands. His physicians prescribed opium, and he-perhaps wisely-would not take that drug. Professional jealousy, especially the increasing popularity of Meyerbeer, aggravated by the ill reception of the Semiramide at Florence, increased his ill-health. He often exclaimed: "What a spiritless, ignorant, filthy age we live in!" In respect to his malady he said: "I suffer from all the ills women complain of-il ne me manque que l'utérus." In age he recovered from his nervous symptoms, and composed a fine Mass in 1869. In fact, he reached an age when he ceased to trouble about the world and his rivals, and so fitted himself for a little more good work.

(BMF 1893;i:34.) 